\title{
The advantage of using operational budgeting on governmental organization
}

\author{
Manouchehr Najafi $^{\mathrm{a}}$ and Ahmad Ahmadkhani ${ }^{\mathrm{b}}$
}

${ }^{a}$ Department of Accounting, Islamic Azad University, Hamedan Branch, Hamedan, Iran

${ }^{b}$ Young researchers club, Zanjan Branch, Islamic Azad University, Zanjan, Iran

\begin{tabular}{l}
\hline A R T I C L E I N F O \\
\hline Article history: \\
Received July 18, 2011 \\
Received in Revised form \\
September, 2, 2011 \\
Accepted 12 September 2011 \\
Available online \\
28 September 2011 \\
\hline Keywords: \\
Operating budgeting \\
Accounting \\
Governmental budgeting \\
Performance measurement
\end{tabular}

Performance measurement \begin{abstract}
A B S T R A C T
Budgeting plays an important role on increasing efficiency of organizations. It helps determine targets and possible future chaos a head of time. A good budgeting plan can create motivation among workers and managers. There are different budgeting plans such as traditional and operational. In this paper, we analyze the effects of executing budgeting plan on governmental organizations. The proposed study of this paper designs a questionnaire consists of various questions and selects 94 people out of 125 financial managers who work for various governmental organizations in province of Zanjan, Iran. The results indicate that the operational budgeting could help provide better performance measurement of governmental organizations, it helps us provide a more precise cost of products and services, and it helps government allocate the necessary budget proportion to performance measurement. The results of our survey also indicate that operational budgeting redirect costs towards our objectives and make the overall budgeting crystal clear.
\end{abstract}

\section{Introduction}

Building a governmental budget is the act of combining government's income and expenses to decide the amount of budget to spend on every necessary activity. Building an appropriate budget helps determine government's financial health and stability. There are various methods of designing a budget and governmental budgeting is one of the most important ones. Operational budgeting is a method for developing financial plans for the organization, typically for a year. While annual budgets do not require to be subdivided into shorter periods, monthly or quarterly budgets are normally essential for anticipating cash needs and for comparing actual experience with plan. A comprehensive master budget needs planning for all phases of the operations such as sales, marketing, manufacturing, engineering and general administration. In the United States, all businesses along with state and local governments use two systems of budgeting, which are the operating budget and capital budget.

\footnotetext{
* Corresponding author. Tel: +09124413790

E-mail addresses: najafi1420@yahoo.com (M. Najafi) 
The operating budget is implemented to monitor of maintenance operations, salaries, and interest payments. Operating budget has many advantages such as measuring the performance of an organization, promoting the people who reach the organization's goals and predicting redlines and possible shortage on cash flow in future. A good operational budgeting could create crystal clear and in some cases we may make the whole information of the budget publicly available (Foltin, 1999; Andrews \& Hill, 2003; Pérez et al., 2005; Weygandt, 2009; Atkinson et al., 2011). There are many studies associated with the impact of operational budgeting. Joiner and Drake (1983) explained that governmental planning and budgeting could follow different objectives and presented a goal programming model for a state level public health care agency.

Pendlebury and Jones (1985) explained that for many years the academic governmental-budgeting literature used to concentrate almost on the politics and economics of the budgetary process at the cost of the mechanical foundations. They argue that we do not see any discussion of the accounting perspective. They offered such a discussion by explaining local government budgeting as "ex ante financial accounting" and offered some necessary implications of this re-interpretation. Henry and Attavitkamtorn (1999) presented the current state of governmental accounting and auditing in Thailand and provided some recommendations for improving the reporting and auditing of financial information to facilitate government decision making with the existing economic crisis.

Fisher (1999) explained the political issues affecting congressional budgeting. He explained that the American public is normally looking for contradictory budgetary actions from its representatives in Congress. Congress is a responsive body on budgetary matters, as can be seen by the strong correlations between demographics and congressional budget votes. He concluded that the contradictory desires of the American public must be modified; otherwise, congressional budgeting is destined to be viewed as flawed and inadequate. Verbeeten (2011) discussed public sector cost management practices in The Netherlands and reported that the design and use of cost management systems varies across branches. Besides, their results suggested that information from cost management systems is used to legitimate the organization's activities to external stakeholders rather than to manage public sector organizations. Mace \& Brumby (2005) performed a comprehensive review on the impact of operational budgeting on performance measurement in governmental levels and concluded that there are many evidences to believe that we could improve governmental efficiency through a precise budgeting program.

The proposed study of this paper measures the impact of operational accounting on one of the provinces of Iran called Zanjan. The orientation of this paper first presents details of the sampling and the questions of the research in section 2. Section 3 explains the results of our survey and finally concluding remarks are given in section 4 to summarize the contribution of this paper.

\section{Proposed research study}

The primary objective of this proposed study is to know whether operational budgeting could contribute to increase governmental performance measurement or not. To answer this question we have setup five main questions as follows,

1. Does operational budgeting provide better performance measurement for governmental organizations?

2. Does operational budgeting provide a more precise cost of products and services?

3. Does operational budgeting help government allocate the necessary budget proportion to performance measurement?

4. Does operational budgeting redirect costs towards our objectives?

5. Does operational budgeting provide budgeting transparency? 
The proposed study of this research study uses a questionnaire and distributes among all 125 financial managers who work for different governmental agencies located in Zanjan/Iran. The sample size is calculated using the following,

$n \geq \frac{N z^{2} p q}{(N-1) d^{2}+z^{2} p q}$,

Where $n$ is the sample size, $N$ is the size of population, $d$ is an error term which is considered as 0.05 in this study, $z=1.96$ and $p=q=0.5$. Therefore, we need 94 experts to participate in our survey from various governmental organizations. The questions are designed based on Likert scales in four choices from completely disagree to completely agree. Out of 94 people who participated in our survey, 69 people representing $73.4 \%$ were male and 25 people representing $26.6 \%$ were female. In terms of educational background, they were highly educated since $74.5 \%$ of the participants maintained a minimum bachelor or master degrees, 19.1\% held 2 years of university education and the remaining $6.4 \%$ had finished high school. The people who participated in our survey had different positions with $47.9 \%$ were financial expert, $39.1 \%$ budgeting expert, $6.4 \%$ financial manager and $13.8 \%$ had other expertise. They participants were mostly experienced people and $89.4 \%$ of them had at least 5 years of job experience.

\section{The results}

In this section, we explain details of our survey results based on the information we gathered. As we explained, the questions were designed based on four Likert scales from completely disagree to completely agree. Therefore we divide them into two groups where the replies of completely disagree and disagree are considered in one group and the responses of agree and completely agree were considered in other group. Therefore, we can use binomial test to verify the responses for each questions as follows,

$$
z=\frac{X-n p}{\frac{\sqrt{n p q}}{N}}
$$

where $n, p, q, X, N$ and $z$ are sample size, the chance of success, the chance of failure, the number of success, population size and normal statistical indicator, respectively. We consider $p=q=0.5$ for all five questions. Table 1 summarizes the result of our survey for the first question.

\section{Table 1}

The details of the first hypothesis $H_{0}: p \leq 0.50$ against $H_{1}: p>0.50$

\begin{tabular}{lcccll}
\hline Groups & Numbers & $p$ & Ratio & Significance level & Result \\
\hline For & 92 & 0.96 & \multirow{2}{*}{0.50} & \multirow{2}{*}{0.000} & \multirow{2}{*}{ Confirmed } \\
\hline Against & 2 & 0.04 & & & \\
\hline
\end{tabular}

As we can observe from the results of Table 1, the first hypothesis is strongly confirmed, which means operational budgeting provides better performance measurement for governmental organizations. Similarly, Table 2 provides details of our survey for the second question.

Table 2

The details of the second hypothesis $H_{0}: p \leq 0.50$ against $\quad H_{1}: p>0.50$

\begin{tabular}{lcccll}
\hline Groups & Numbers & $p$ & Ratio & Significance level & Result \\
\hline For & 87 & 0.93 & \multirow{2}{*}{0.50} & \multirow{2}{*}{0.000} & \multirow{2}{*}{ Confirmed } \\
\hline Against & 7 & 0.07 & & & \\
\hline
\end{tabular}


According to the results of Table 2, the second hypothesis is strongly confirmed or operational budgeting provides a more precise cost of products and services. Table 3 shows details of our survey for the third hypothesis.

Table 3

The details of the third hypothesis $H_{0}: p \leq 0.50$ against $H_{1}: p>0.50$

\begin{tabular}{lcccll}
\hline Groups & Numbers & $p$ & Ratio & Significance level & Result \\
\hline For & 87 & 0.93 & \multirow{2}{*}{0.50} & \multirow{2}{*}{0.000} & \multirow{2}{*}{ Confirmed } \\
\hline Against & 7 & 0.07 & & & \\
\hline
\end{tabular}

Based on the results we get from Table 3, it is clear that operational budgeting helps government allocate the necessary budget proportion to performance measurement. Next, we report the results of our survey for fourth question of our survey in Table 4.

\section{Table 4}

The details of the fourth hypothesis $H_{0}: p \leq 0.50$ against $H_{1}: p>0.50$

\begin{tabular}{lcccll}
\hline Groups & Numbers & $p$ & Ratio & Significance level & Result \\
\hline For & $\mathbf{8 8}$ & 0.94 & \multirow{2}{*}{0.50} & \multirow{2}{*}{0.000} & \multirow{2}{*}{ Confirmed } \\
\hline Against & $\mathbf{6}$ & 0.06 & & \\
\hline
\end{tabular}

It is clear that almost all people were interested in our fourth hypothesis, which means operational budgeting can simply redirect costs towards our objectives. Finally, Table 5 is associated with our last hypothesis.

Table 5

The details of the fourth hypothesis $H_{0}: p \leq 0.50$ against $\quad H_{1}: p>0.50$

\begin{tabular}{lcccll}
\hline Groups & Numbers & $p$ & Ratio & Significance level & Result \\
\hline For & $\mathbf{8 6}$ & 0.91 & \multirow{2}{*}{0.50} & \multirow{2}{*}{0.000} & \multirow{2}{*}{ Confirmed } \\
\hline Against & 8 & 0.09 & & & \\
\hline
\end{tabular}

The results of Table 5 also explain that operational budgeting provides clear bills and we can move towards having crystal clear reports.

We have also performed Freedman test (Kendall, 1970) for difference questions of our survey. Table 6 shows the Freedman rankings of different operational budgeting items influencing financial control.

\section{Table 6}

The results of Freedman ranking for operational budgeting issues

\begin{tabular}{l}
\hline Item \\
$\begin{array}{l}\text { Operational budgeting could build link between budgetary decisions and } \\
\text { governmental performance, which could improve government's position in response }\end{array}$ \\
to people \\
$\begin{array}{l}\text { We can increase the quality of services through encouraging managers to use } \\
\text { operational budgeting. }\end{array}$ \\
$\begin{array}{l}\text { Operational budgeting is a suitable tool to increase performance of governmental } \\
\text { agencies }\end{array}$ \\
$\begin{array}{l}\text { Operational budgeting is a suitable tool to control financial tasks } \\
\text { Operational budgeting is a suitable tool to improve all tasks }\end{array}$ \\
\hline
\end{tabular}

As we can see from the results of Table 6, operational budgeting plays an important role on increasing people's satisfaction on government's responsibilities. The second question was associated 
with the relationship between facilitating cost calculation of services and operational budgeting and Table 7 summarizes the results of our survey for this question.

Table 7

The results of Freedman ranking for the relationship between operational budgeting and cost of services Item

All managers must follow unique operations to reach comprehensive cost calculation Average ranking p-value operations.

All budgets must be allocated based on the objectives of the budget. 2.87

Operational budgeting will increase management's abilities to make better decisions.

It is clear that a unique operational budgeting could help us calculate the cost of services and this item receives the highest ranking in our survey.

\section{Table 8}

The results of Freedman ranking for allocating budget based on the performance

\begin{tabular}{lcc}
\hline Item & Average ranking & p-value \\
\hline In operational budgeting, different divisions receive funding based on their & 3.23 \\
performances. & 3.07 \\
In operational budgeting, annual and multi-year performance measurement plays an & 3.02 \\
important role on making strategic decisions. & 2.27 \\
Performance measurement attributes are important factors in operational budgeting. & 2.73 \\
The performance of an organization is measured based on pre-specified attributes. & 0.000 \\
\hline Operating budgeting determines performance measurement. &
\end{tabular}

We can observe from the results of Table 8 that operating budgeting plays an important role for measuring the performance of governmental organizations. Table 9 shows the results of our survey on

\section{Table 9}

The Freedman results for the relationship between the ranking operational budgeting and cost allocation proportion to objectives

\begin{tabular}{|c|c|c|}
\hline Item & Average ranking & p-value \\
\hline In operational budgeting, management is more responsive to budget. & 2.68 & \multirow{5}{*}{0.000} \\
\hline Operational budgeting creates more decisions that are effective. & 2.52 & \\
\hline Based on operational budgeting, all budgets are allocated based on the objectives. & 2.46 & \\
\hline The performance of an organization is measured based on pre-specified attributes. & 2.27 & \\
\hline Operating budgeting helps concentrates on more challenging decisions. & 2.35 & \\
\hline
\end{tabular}

Once more, we observe from the results of Table 9 that when we use operational budgeting, management is more responsive to performance measurement. Finally, Table 10 summarizes the results of our survey on budget transparency based when operational budgeting is applied.

\section{Table 10}

The Freedman results for the relationship between the ranking operational budgeting and budget transparency

\begin{tabular}{lc}
\hline Item & Average ranking \\
\hline Operating budgeting has structural framework, which can be implemented, properly. & 3.09 \\
Operational budgeting forces organizations to be more responsible on reaching & 3.08 \\
organizations' objectives. & 3.02 \\
$\begin{array}{l}\text { Based on operational budgeting, budget allocation does not depend on people's will } \\
\text { and it is based on the precise objectives. }\end{array}$ & 2.81 \\
Operating budgeting will improve managements' responses. & 2.01 \\
Operating budgeting improves budgeting transparency. & 0.000 \\
\hline
\end{tabular}


In summary, we can conclude that the operating budgeting helps governmental organizations reach high quality services through specifying details of budgeting process. It provides better performance measurement for governmental organizations; it helps us reach a more precise cost for products and services; operational budgeting allocates the necessary budget proportion to performance measurement; it redirects costs towards our objectives and it will lead us to reach transparent budget.

\section{Conclusion}

In this paper, we have presented an empirical study to measure the effects of operational budgeting on the performance of government agencies. The proposed study of this paper designed a questionnaire based on various questions in Likert based and distributed among 94 out of 125 people who were responsible in different fields of management. There were five main questions in our survey for measuring the effect of operational budgeting on the performance of governmental agencies. The results indicated that all our hypothesis were confirmed, which means operational budgeting helps governmental organizations reach high quality services through specifying details of budgeting process. It provides better performance measurement for governmental organizations; it helps us reach a more precise cost for products and services; operational budgeting allocates the necessary budget proportion to performance measurement; it redirects costs towards our objectives and it will lead us to reach transparent budget.

\section{Acknowledgment}

Young researchers club of Islamic Azad University financially supported this paper and the authors would like to express their thanks.

\section{References}

Andrews, M., \& Hill, H. (2003). The impact of traditional budgeting systems on the effectiveness of performance - based budgeting: a different viewpoint on recent findings. International Journal of public Administration, 26(2), 135 - 155.

Atkinson, A. A., Kaplan, R. S., Matsumura, E. M., \& Young, S.M. (2011). Management Accounting: Information for Decision Making and Strategy Execution. $6^{\text {th }}$ ed. Pearson Education, Inc.

Fisher, P. (1999). Political explanations for the difficulties in congressional budgeting. The Social Science Journal, 36(1), 149-161.

Foltin, C. (1999). State Local Government Performance it time to measure up. The Government Accountant Journal, 48(1), 40-46.

Henry, L.J., \& Attavitkamtorn, P. (1999). Governmental accounting and auditing in Thailand: an overview and some suggestions for improvement. The International Journal of Accounting, 34(3), 439-454.

Joiner, C., \& Drake, A. E. (1983). Governmental planning and budgeting with multiple objective models. Omega, 11(1), 57-66.

Kendall, M. G. (1970). Rank Correlation Methods. $4^{\text {th }}$ ed., London, Charles Griffin.

Mace, R., \& Brumby, J. (2005). Does performance Budgeting Work? An analytical review of the empirical literature, International Monetary Fund.

Pendlebury, M., \& Jones, R. (1985).Governmental budgeting as ex ante financial accounting: The United Kingdom case. Journal of Accounting and Public Policy, 4(4), 301-316.

Pérez, C.C., Hernández, A.M.L., Bolívar, M.P.R. (2005).Citizens' access to on-line governmental financial information: Practices in the European Union countries. Government Information Quarterly, 22(2), 258-276.

Verbeeten, F.H.M. (2011). Public sector cost management practices in The Netherlands. International Journal of Public Sector Management, 24(6), 492-506.

Weygandt, J.J., Kimmel, P.D., \& Kieso, D. E. (2009). Managerial Accounting: Tools for Business Decision Making. Wiley. 